\title{
Review: Alternative and novel feeds for ruminants: nutritive value, product quality and environmental aspects
}

\author{
A. Halmemies-Beauchet-Filleau ${ }^{1 \dagger}{ }^{,}$M. Rinne ${ }^{2}$, M. Lamminen ${ }^{1,3}$, C. Mapato ${ }^{4}$, T. Ampapon ${ }^{4}$, \\ M. Wanapat ${ }^{4}$ and A. Vanhatalo ${ }^{1,3}$ \\ ${ }^{1}$ Department of Agricultural Sciences, University of Helsinki, Fl-00014 Helsinki, Finland; ${ }^{2}$ Production Systems, Natural Resources Institute Finland (Luke), Fl-31600 \\ Jokioinen, Finland; ${ }^{3} \mathrm{Helsinki}$ Institute of Sustainability Science, University of Helsinki, Fl-00014 Helsinki, Finland; ${ }^{4}$ Department of Animal Science, Tropical Feed \\ Resources Research and Development Center, Faculty of Agriculture, Khon Kaen University, Khon Kaen 40002, Thailand
}

(Received 30 April 2018; Accepted 13 August 2018; First published online 15 October 2018)

Ruminant-based food production faces currently multiple challenges such as environmental emissions, climate change and accelerating food-feed-fuel competition for arable land. Therefore, more sustainable feed production is needed together with the exploitation of novel resources. In addition to numerous food industry (milling, sugar, starch, alcohol or plant oil) side streams already in use, new ones such as vegetable and fruit residues are explored, but their conservation is challenging and production often seasonal. In the temperate zones, lipid-rich camelina (Camelina sativa) expeller as an example of oilseed by-products has potential to enrich ruminant milk and meat fat with bioactive trans-11 18:1 and cis-9,trans-11 18:2 fatty acids and mitigate methane emissions. Regardless of the lower methionine content of alternative grain legume protein relative to soya bean meal (Glycine max), the lactation performance or the growth of ruminants fed faba beans (Vicia faba), peas (Pisum sativum) and lupins (Lupinus sp.) are comparable. Wood is the most abundant carbohydrate worldwide, but agroforestry approaches in ruminant nutrition are not common in the temperate areas. Untreated wood is poorly utilised by ruminants because of linkages between cellulose and lignin, but the utilisability can be improved by various processing methods. In the tropics, the leaves of fodder trees and shrubs (e.g. cassava (Manihot esculenta), Leucaena sp., Flemingia sp.) are good protein supplements for ruminants. A foodfeed production system integrates the leaves and the by-products of on-farm food production to grass production in ruminant feeding. It can improve animal performance sustainably at smallholder farms. For larger-scale animal production, detoxified jatropha (Jatropha sp.) meal is a noteworthy alternative protein source. Globally, the advantages of single-cell protein (bacteria, yeast, fungi, microalgae) and aquatic biomass (seaweed, duckweed) over land crops are the independence of production from arable land and weather. The chemical composition of these feeds varies widely depending on the species and growth conditions. Microalgae have shown good potential both as lipid (e.g. Schizochytrium sp.) and protein supplements (e.g. Spirulina platensis) for ruminants. To conclude, various novel or underexploited feeds have potential to replace or supplement the traditional crops in ruminant rations. In the short-term, $\mathrm{N}$-fixing grain legumes, oilseeds such as camelina and increased use of food and/or fuel industry by-products have the greatest potential to replace or supplement the traditional crops especially in the temperate zones. In the long-term, microalgae and duckweed of high-yield potential as well as wood industry by-products may become economically competitive feed options worldwide.

Keywords: legume, by-product, single-cell protein, tree, ruminant

\section{Implications}

Within ruminant-based food production, there are potential means to improve global food supply and to decrease its environmental footprint without compromising animal products. Alternative and novel feeds provide opportunities to (a) spare arable land, fresh water (e.g. single-cell proteins

\footnotetext{
${ }^{\dagger}$ E-mail: anni.halmemies@helsinki.fi
}

(SCP), duckweed) or fertilisers ( $\mathrm{N}$-fixing grain and shrub legumes), (b) exploit side streams more efficiently (residues of food, biofuel or wood production) and (c) increase the use of fibrous feeds not suitable for monogastrics (wood, shrubs). They may also offer additional benefits such as modification of lipids in ruminant products (lupins, camelina, microalgae) and mitigation of methane emissions (lipid-rich feeds, tropical shrubs). 


\section{Introduction}

Ruminant-based food production faces currently multiple and global challenges such as needs to respond to the growing human population and food security, but also to the pollution of environment and the accelerating climate change. The animal production sector is also heavily criticised due to food-feed competition, that is, the feeding of human-edible materials to animals and the use of arable land to produce animal feed instead of producing humanedible food directly. Recently increasing interest in biofuel production tightens up the competition on the use of arable land.

Ruminants are often criticised for the lower feed conversion efficiency relative to monogastric livestock, but taking into account differences in the feed rations modifies the ranking order. Indeed, to produce the same amount of animal protein products (meat, milk or eggs) much less human-edible feed is needed in ruminant systems than in monogastric systems $(6 \mathrm{v} .16 \mathrm{~kg}$ of human-edible feed dry matter (DM) per kilogram of protein products; Mottet et al., 2017). The strengths inherent to ruminant animals in food production chain could be further developed by more diverse and efficient exploitation of side streams and increased exploitation of fibrous feeds not suitable for the nutrition of humans and monogastric livestock. To improve the food system sustainability and to reach climate change targets, changes in feed and animal production alone are not adequate. Changes in food consumption as regard to wastage and balanced dietary choices are also needed (Röös et al., 2017). According to Schader et al. (2015), feeding animals solely based on food industry by-products and grasslands combined with changes in human dietary patterns (reductions of animal products) have potential to decrease the environmental load of food production drastically. For example, greenhouse gas emissions, nitrogen $(\mathrm{N})$ and phosphorus (P) load, as well as land and fresh water use could decrease up to $18 \%$ to $46 \%$.

Almost half of worldwide bovine milk production takes place in the temperate areas of Europe and Northern America (FAOSTAT, 2016) under intensive (high inputs including concentrate, high milk yield) or extensive production systems (high forage, low inputs, moderate or low milk yield). At the present, the ruminant milk and meat production in Europe relies largely on imported soya bean (Glycine max) from South America (Lindberg et al., 2016). Soya bean together with cereals and maize (Zea mays), lucerne (Medicago sativa) or grass forage are typical dietary ingredients in the intensive farming of the temperate zones. However, the highest cattle populations are in the tropical and subtropical climate zones, the number of cattle in Brazil and India alone comprising $15 \%$ and $13 \%$ of global cattle population, respectively (FAOSTAT, 2016). In the tropics, the forages are typically of poor nutritive value in terms of low protein and high-fibre content that limits the efficiency of animal production. Local protein sources are thus sought both in the temperate as well as tropical areas.
Enteric methane emissions from ruminants significantly contribute to the environmental footprint of agriculture (Herrero et al., 2016). Ruminal methane production also represents a substantial loss of feed energy. Appropriate forage supplementation and feed choices to improve forage and total diet digestibility have significantly more potential to increase ruminant performance and mitigate methane emissions in the extensive than in the intensive ruminant production systems (Knapp et al., 2014; Herrero et al., 2016). Modern intensive agriculture is a significant source of $\mathrm{N}$ emissions as well. Globally, about $50 \%$ of the $\mathrm{N}$ fertiliser applied to conventional cropping systems is not utilised by plants, but lost to the environment as ammonia $\left(\mathrm{NH}_{3}\right)_{\text {, }}$ nitrate $\left(\mathrm{NO}_{3}^{-}\right)$and nitrous oxide $\left(\mathrm{N}_{2} \mathrm{O}\right.$; Coskun et al., 2017). Legumes with biological $\mathrm{N}_{2}$ fixation (Watson et al., 2017) may offer an environmentally sound and sustainable nutrient source to ruminants. Furthermore, the $\mathrm{N}$ use efficiency of ruminants is mainly determined by diet $\mathrm{N}$ content (Huhtanen et al., 2008) indicating the potential to reduce $\mathrm{N}$ leakages by dietary $\mathrm{N}$ optimisation.

The feasibility of using alternative feeds for ruminants depends among others on the feed value of novel feeds, animal production responses and feed costs compared to the conventional feeds. In addition, the environmental footprint of feed and animal production, and the economic value of novel feeds in alternative uses such as energy production are of great importance. The objective of this article is to review the nutritive value of some currently underutilised or novel feeds for ruminants in the temperate zones (intensive and extensive farming) and in the tropics (extensive farming). In addition, the effects of these feeds on ruminant milk production and quality (milk, protein and fat yields and milk fatty acid composition) as well as meat production (average daily gains (ADG) and meat composition) are examined and compared to more conventional feeds. The environmental load of novel feeds is evaluated based on requirements for arable land and for fresh water during the feed production and their possible effects on methane and nitrogen emissions of ruminants. This review comprises a quantitative evaluation of replacing traditional feeds by alternative ones on ruminant milk production as well as a comparative estimation of time delay for novel feeds to enter readily on the market together with their future potential to increase sustainable production and utilisation in ruminant nutrition.

\section{Intensive and extensive ruminant production in the temperate zones: protein and energy supplements}

\section{By-products of food and bioenergy industries}

Numerous food and biofuel industry side streams are already used as major components of ruminant diets such as hulls and feed meals from milling industry, distillery and brewery by-products, meals and expellers from plant oil production, molasses and pulps from sugar processing, etc. (Feedipedia, 2018; Luke, 2018). Biofuel by-products as ruminant feeds have been reviewed in detail by Makkar et al. (2012). Recent 
attempts have aimed at utilising such side streams that have not previously been used. Wadhwa and Bakshi (2013) estimated that nearly $50 \%$ of all fruits and vegetables in the European Union go to waste with losses occurring during agricultural production, processing, distribution and by consumers. Vegetable residues may be composted and used as soil amendments but with only a limited added value. One option to add value to these products is to preserve them by sun drying (Wadwha et al., 2015) or ensiling (Orosz and Davies, 2015) and feed to livestock. Vegetable and fruit residues are challenging raw materials for ensiling as they are easily perishable and typically moist (Wadwha et al., 2015; Table 1; Supplementary Table S1). Solid-state fermentation of the fruit and vegetable wastes in combination with other non-competing human food biomass could possibly (a) enrich them with proteins and other nutrients, (b) improve feed quality and (c) enhance ensilability (Wadwha et al., 2015).

The production of fruit and vegetable residues is often seasonal, and in many cases they are produced by small or medium size companies, resulting in rather small batches. To be able to recycle these residues back into the food chain requires high hygienic quality of the products and good stability to allow efficient logistics. Some of the major constraints in the use of fruit wastes are the presence of antinutritional factors such as pesticides, mycotoxins, heavy metals and dioxins (Wadhwa et al., 2015). There are, however, positive experiences as, for example, ensiled tomato and olive by-products have been successfully used in the diets of dairy goats (Arco-Pérez et al., 2017) and ensiled apple pomace up to $30 \%$ in the diets of lactating dairy cows (Wadhwa et al., 2015).

By-products of oilseed crops such as soya bean and rapeseed meals and expellers are widely used as supplementary protein for dairy cows. One of the less used oilseed crops is an ancient plant camelina (Camelina sativa). Camelina has a moderate seed yield potential (Table 2) that combined with low-nutrient requirements and a good resistance to diseases, pests and drought makes it adapted also to low-input farming (Heuzé et al., 2017b). Camelinaseed oil is an economically interesting on-farm raw material for biofuel production (Keske et al., 2013) to increase farmers' energy independence. Camelinaseed oil is also fit for human consumption (Heuzé et al., 2017b). Camelina expeller contains lipids with significant amounts of essential fatty acids 18:2n-6 and 18:3n-3 (Bayat et al., 2015), but it is also relatively abundant in CP and essential amino acids (AA) (Table 1). However, ruminal degradability of camelina protein in situ $(76 \%)$ was higher than that of soya bean $(58 \%)$ or rapeseed (52\%; Lawrence and Anderson, 2015). Feeding unprocessed or processed camelinaseeds to ruminants has sometimes, but not always, decreased DM intake (Table 3; Supplementary Table S2; Table 4; Supplementary Table S3) that may be related to glucosinolates (Lawrence et al., 2016). Nevertheless, replacing various conventional protein feeds in ruminant diets with camelina expeller has resulted in comparable milk and protein yields (Table 3) or ADG (Table 4).
Feeding camelina expeller results in high concentrations of trans-11 18:1 and cis-9, trans-11 18:2, unaltered or slightly decreased 18:0 and cis-9 18:1 concentrations and a significant decrease in total saturated fatty acids in dairy cow (Halmemies-Beauchet-Filleau et al., 2011 and 2017), in sheep (Szumacher-Strabel et al., 2011) and in goat milk (Cais-Sokolińska et al., 2015) as well as in sheep meat (Table 4). Besides beneficially modifying lipids in ruminant milk and meat, camelina lipids at inclusion rate of $6 \%$ in the diet DM decreased ruminal methane and carbon dioxide production of dairy cows by $29 \%$ and $34 \%$, respectively (Bayat et al., 2015). However, caution should be exercised in the dosage of lipids as the reduction in methane emissions due to the dietary polyunsaturates may be accompanied with lowered DM intake and milk yield (Bayat et al., 2015).

\section{Grain legume seeds}

Grain legumes such as faba bean (Vicia faba), pea (Pisum sativum) and lupins (Lupinus sp.) are old crops cultivated in all arable continents. There are three major modern lupine species bred to animal feed namely white (Lupinus albus), blue (Lupinus angustifolius) and yellow lupin (Lupinus luteus). In the short-term, grain legumes are presumably the most promising alternatives to soya bean (Glycine max) and rapeseed in the temperate areas because their cultivation practices are already available and implemented (Figure 1). However, grain legume seeds are edible by humans as well. Therefore, the utilisation of human-inedible feeds for ruminants and/or feeds the production of which require less or not at all arable land should be encouraged to improve further the sustainability of food production system in the longer term.

The unique capacity of leguminous plants in conjunction with rhizobium symbionts to biologically fix and utilise atmospheric $\mathrm{N}$ enables that inorganic $\mathrm{N}$-fertilisers with rising prices and high requirement of energy in manufacturing are not required. Indeed, the emissions of a potent greenhouse gas $\mathrm{N}_{2} \mathrm{O}$ from legume cultivation are generally lower than those from N-fertilised crops (1.3 v. $3.2 \mathrm{~kg} / \mathrm{ha}$; Watson et al., 2017). The seed yield potential of grain legumes under optimal conditions is similar or exceeding that of conventional protein crops (Table 2). These advantages make legumes increasingly attractive in the intensive farming in addition to current wide spread use in the low-input and organic farming.

A prerequisite for the spread of grain legume production is the profitability relative to other crops. This is influenced, for example, by yields, volatile producer prices, incentives and production costs. Though the producer prices of grain legume seeds are on average 1.1 to 2.0 times higher than that of wheat in Europe (FAOSTAT, 2016), the competitiveness against more common crops such as wheat is uncertain mainly due to inconsistent DM yields and high seed costs. However, the incentives for protein feeds and reducing the seed costs by producing the seed on-farm can improve the competitiveness of grain legume cultivation. The cultivation 
Halmemies-Beauchet-Filleau, Rinne, Lamminen, Mapato, Ampapon, Wanapat and Vanhatalo

Table 1 Chemical composition of some alternative and common feeds for ruminants

\begin{tabular}{|c|c|c|c|c|c|c|c|c|c|}
\hline \multirow[b]{2}{*}{ Feed $^{1}$} & \multirow{2}{*}{$\begin{array}{l}\text { DM } \\
\mathrm{g} / \mathrm{kg}\end{array}$} & Ash & NDF & Starch & $\mathrm{EE}$ & $\mathrm{CP}$ & His & Met & Lys \\
\hline & & \multicolumn{5}{|c|}{$\mathrm{g} / \mathrm{kg} \mathrm{DM}$} & \multicolumn{3}{|c|}{$\mathrm{g} / \mathrm{kg} \mathrm{CP}$} \\
\hline \multicolumn{10}{|l|}{ Common protein feeds } \\
\hline Rapeseed expeller & 899 & 69 & 299 & & 92 & 391 & 28 & 22 & 56 \\
\hline Soya bean expeller & 907 & 68 & 111 & & 77 & 493 & 27 & 14 & 63 \\
\hline \multicolumn{10}{|l|}{ By-products of food industry } \\
\hline Apple pomace & 360 & 26 & 525 & & 50 & 77 & & & \\
\hline Camelinaseed expeller & 905 & 69 & 305 & 2 & 156 & 357 & 23 & 20 & 46 \\
\hline Cauliflower leaf & 654 & 162 & 145 & & & 126 & & & \\
\hline Cucumber waste & 37 & 113 & 168 & & & 163 & & & \\
\hline Grape marc & 876 & 63 & 658 & & 64 & 115 & 29 & 15 & 45 \\
\hline Tomato fruit waste & 62 & 101 & 191 & & & 103 & & & \\
\hline Olivesilage (pulp + leaf) & 575 & 127 & 390 & & & 88 & & & \\
\hline \multicolumn{10}{|l|}{ Grain legume seeds } \\
\hline Faba bean & 866 & 39 & 159 & 447 & 14 & 290 & 26 & 8 & 62 \\
\hline Lupin, blue & 915 & 42 & 253 & 122 & 63 & 332 & 28 & 7 & 50 \\
\hline Lupin, white & 912 & 43 & 235 & 84 & 105 & 344 & 23 & 8 & 50 \\
\hline Lupin, yellow & 898 & 54 & 254 & 35 & 53 & 435 & 27 & 7 & 50 \\
\hline Pea & 865 & 35 & 142 & 513 & 12 & 239 & 25 & 10 & 72 \\
\hline Soya bean & 887 & 57 & 132 & 64 & 214 & 396 & 26 & 14 & 62 \\
\hline Grass silage juice & 98 & 193 & & & & 190 & & & \\
\hline \multicolumn{10}{|l|}{ Grain legume whole crop stands } \\
\hline Faba bean & 168 & 62 & 387 & 82 & & 175 & & & \\
\hline Lupin, white & 142 & 68 & 395 & & & 169 & & & \\
\hline Pea & 198 & 65 & 397 & 67 & & 167 & & & \\
\hline \multicolumn{10}{|c|}{ Trees or shrubs (leaves unless otherwise stated) } \\
\hline Cassava & 250 & 126 & 459 & & & 223 & & $46^{2}$ & \\
\hline Flemingia & 290 & 53 & 531 & & & 258 & & $58^{2}$ & \\
\hline Leucaena & 320 & 64 & 316 & & & 205 & & $36^{2}$ & \\
\hline Moringa & 330 & 115 & 219 & & 54 & 251 & 31 & 21 & 66 \\
\hline Pine bark & & 22 & 667 & & 47 & 28 & & & \\
\hline Sesbania & 290 & 103 & 258 & & & 233 & & & \\
\hline Willow & 264 & 71 & 573 & & & 167 & & & \\
\hline Jatropha kernel meal, detoxified & 876 to 971 & 79 to 136 & 98 to 200 & 68 to 120 & 4 to 52 & 624 to 775 & 27 to 33 & 14 to 17 & 30 to 36 \\
\hline \multicolumn{10}{|l|}{ Single-cell protein } \\
\hline Bacteria & & 30 to 70 & & & 10 to 30 & 500 to 650 & 23 & 30 & 61 \\
\hline Fungi & & 90 to 140 & & & 20 to 80 & 300 to 450 & 15 to 20 & 15 to 17 & 38 to 61 \\
\hline \multicolumn{10}{|l|}{ Microalgae } \\
\hline Chlorella vulgaris & 946 & 57 & 0 & 43 & 95 & 608 & 18 & 19 & 49 \\
\hline Euglena gracilis & 960 & 35 & 0 & & 138 & 240 & 26 & 20 & 66 \\
\hline Scenedesmus obliquus & & 60 to 100 & & & 120 to 140 & 500 to 600 & 15 to 17 & 12 to 21 & 50 to 57 \\
\hline Schizochytrium sp. & & 82 & $6^{3}$ & & 380 to 710 & 121 & 8 & $<8$ & 33 \\
\hline Spirulina platensis & 940 & 70 & 0 & 64 & 55 & 692 & 16 & 22 & 39 \\
\hline Yeast & & 50 to 100 & & & 20 to 60 & 450 to 550 & 21 to 22 & 13 to 21 & 74 to 77 \\
\hline \multicolumn{10}{|l|}{ Seaweed } \\
\hline Ascophyllum nodosum & 100 to 300 & 225 & 209 & & 39 & 80 & 14 & 13 & 46 \\
\hline Macrocystis pyrifera & 100 to 300 & 320 & 199 & & 6 & 101 & 13 & 19 & 47 \\
\hline Ulva spp. & 100 to 300 & 230 & 262 & & 12 & 186 & 20 & 16 & 38 \\
\hline Duckweed & 56 & 159 & 401 & & 61 & 291 & 17 & 8 & 39 \\
\hline
\end{tabular}

$\mathrm{EE}=$ ether extract.

${ }^{1}$ References in Supplementary Table S1.

${ }^{2}$ Tannins g/kg dry matter (DM).

${ }^{3}$ Crude fibre.

of grain legumes is more challenging than that of cereals and grasses as they are sensitive to lodging and due to pests and pathogens they require efficient crop rotation (van Krimpen et al., 2013). Nevertheless, the plant breeding may be able to overcome these agronomical constraints if given enough attention and resources.

Grain legume seeds differ in the chemical composition, the CP content ranging from 240 (peas) to $400 \mathrm{~g} / \mathrm{kg}$ DM (soya beans). 
Table 2 The suitability for local production of some common and alternative feeds in different production systems, potential yields in Europe, the need of land or water for feed production, and other main environmental aspects regarding crop and ruminant production

\begin{tabular}{|c|c|c|c|c|c|c|c|c|}
\hline \multirow[b]{2}{*}{ Feed } & \multicolumn{3}{|c|}{ Local production } & \multicolumn{2}{|c|}{$\begin{array}{l}\text { Yield } \\
\text { (t/ha) }\end{array}$} & \multicolumn{2}{|c|}{ Need for } & \multirow[b]{2}{*}{ Other environmental aspects } \\
\hline & TInt & TExt & Tropics & DM & $\mathrm{N}$ & Land & $\begin{array}{l}\text { Fresh } \\
\text { water }\end{array}$ & \\
\hline \multicolumn{9}{|l|}{ Common feeds } \\
\hline Rapeseeds & Yes & Yes & & $\begin{array}{l}1.5 \\
\text { to } 3\end{array}$ & $\begin{array}{l}0.6 \\
\text { to } \\
1.2\end{array}$ & Arable & High & Need for $\mathrm{N}$ fertilisation to get high yields ${ }^{1}$ \\
\hline Soya beans & Yes & Yes & Yes & 3 & 0.8 & Arable & High & $\begin{array}{l}\text { Legume, but day length and temperature restricts yield potential and } \\
\text { expansion to northern periphery }\end{array}$ \\
\hline Wheat & Yes & Yes & (Yes) & 10 & 1.1 & Arable & High & Need for $\mathrm{N}$ fertilisation to get high yields \\
\hline Grass forage & Yes & Yes & (Yes) & $\begin{array}{l}10 \\
\text { to } \\
15\end{array}$ & $\begin{array}{l}1.2 \\
\text { to } 2\end{array}$ & Arable & High & Need for $\mathrm{N}$ fertilisation to get high yields, or inclusion of forage legumes \\
\hline \multicolumn{9}{|l|}{ Alternative feeds } \\
\hline Camelina seeds & Yes & Yes & & 3 & 0.8 & Arable & High & $\begin{array}{l}\text { Modest needs for cultivation compared to rapeseed } \\
\text { Polyunsaturates of Camelina lipid may decrease ruminal methane } \\
\text { emissions }^{2}\end{array}$ \\
\hline $\begin{array}{l}\text { Legume grains } \\
\text { peas, beans, lupins }\end{array}$ & Yes & Yes & (Yes) & $\begin{array}{l}4 \text { to } \\
6\end{array}$ & $\begin{array}{l}1 \text { to } \\
2\end{array}$ & Arable & High & $\begin{array}{l}\text { Legumes, therefore no need for } \mathrm{N} \text { fertilisation. High ruminal degradability of } \\
\text { protein and unbalanced amino acid profile of undegradable protein may } \\
\text { increase } \mathrm{N} \text { emissions from ruminants }{ }^{3}\end{array}$ \\
\hline Legume forage & Yes & Yes & & 13 & 2.5 & Arable & High & $\begin{array}{l}\text { Legumes, therefore no need for } \mathrm{N} \text { fertilisation. Due to lower fibre content, } \\
\text { legume forages may mitigate ruminal methane emissions }\end{array}$ \\
\hline Hemicellulose & & Yes & Yes & & & Forest & High & $\begin{array}{l}\text { Low in } N \text { and } P \text {. Incorporation in the diet may improve } N \text { and } P \text { use efficiency } \\
\text { if basal diet is excessive in these nutrients }\end{array}$ \\
\hline $\begin{array}{l}\text { Leaves (tropical } \\
\text { trees and shrubs) }\end{array}$ & & & Yes & & & Forest & High & $\begin{array}{l}\text { Secondary compounds in certain species may direct rumen fermentation } \\
\text { towards propionate and thus mitigate methane }{ }^{4}\end{array}$ \\
\hline Jatropha fruit & & & Yes & $\begin{array}{l}2.5 \\
\text { to } \\
5^{5}\end{array}$ & $\begin{array}{l}1.7 \\
\text { to } \\
3.4^{5}\end{array}$ & $\begin{array}{l}\text { Arable } \\
\text { Forest }\end{array}$ & High & $\begin{array}{l}\text { Decrease soil erodibility due to lateral roots. }{ }^{5} \text { Utilisation of jatropha kernel } \\
\text { meal that is a by-product of oil extraction as animal feed improves overall } \\
\text { nutrient recycling }\end{array}$ \\
\hline $\begin{array}{l}\text { Single-cell protein } \\
\text { excluding } \\
\text { microalgae }\end{array}$ & Yes & Yes & Yes & & & No & Low & $\begin{array}{l}\text { Can recover nutrients from wastewaters and transform low-value organic } \\
\text { by-products to feed }\end{array}$ \\
\hline Microalgae & Yes & Yes & Yes & $\begin{array}{l}15 \\
\text { to } \\
30\end{array}$ & $\begin{array}{l}4 \text { to } \\
15\end{array}$ & No & Low & $\begin{array}{l}\text { Can recover nutrients from wastewaters. Based on chemical composition, } \\
\text { species rich in lipids and low in fibre may have potential to mitigate } \\
\text { ruminal methane emissions. Ruminal protein metabolism warrants } \\
\text { further research }\end{array}$ \\
\hline Seaweed & & (Yes) & (Yes) & 25 & $\begin{array}{l}2.5 \\
\text { to } \\
7.5\end{array}$ & No & No & $\begin{array}{l}\text { Harvesting in the wild decreases nutrient loading of marine environment, } \\
\text { but effective cultivation and harvesting may impair the equilibrium of } \\
\text { coastal ecosystems }{ }^{6}\end{array}$ \\
\hline Duckweed & Yes & Yes & Yes & $\begin{array}{l}30 \\
\text { to } \\
40\end{array}$ & $\begin{array}{l}10 \text { to } \\
18\end{array}$ & No & Low & Can recover nutrients from wastewaters \\
\hline
\end{tabular}

TInt = intensive temperate production; TExt = extensive temperate production; DM = dry matter; Yes = suitable; (Yes) = suitable with some restrictions such as species or cultivars (pulses, grass and wheat) or the proximity of the seaside (seaweed).

${ }^{1}$ Van Krimpen et al. (2013).

${ }^{2}$ Bayat et al. (2015).

${ }^{3}$ Watson et al. (2017).

${ }^{4}$ Table 5.

${ }^{5}$ Yield potential in tropical areas; Heuzé et al. (2016b).

${ }^{6}$ Makkar et al. (2016).

Soya beans have in general the highest ether extract (EE) content, whereas faba beans and peas contain significant amounts of starch and lupin seeds NDF (Table 1). The main storage carbohydrate of lupins is pectin instead of starch (White et al., 2007). Lupin seeds contain more EE than faba beans and peas
(Table 1) with cis-9 18:1 and 18:2n-6 as major fatty acids (White et al., 2007). The protein in grain legume seeds, faba beans and lupin seeds in particular, is low in methionine (Table 1), which is often the limiting AA for the lactation performance of dairy cows (e.g. Pisulewski et al., 1996). 
Halmemies-Beauchet-Filleau, Rinne, Lamminen, Mapato, Ampapon, Wanapat and Vanhatalo

Table 3 The effect of some alternative protein feeds on milk production of ruminants

\begin{tabular}{|c|c|c|c|c|c|c|c|c|c|c|c|c|}
\hline \multirow[b]{2}{*}{ Species } & \multirow[b]{2}{*}{$\begin{array}{l}\text { Alternative } \\
\text { protein feed }\end{array}$} & \multirow[b]{2}{*}{$\begin{array}{c}\text { Control } \\
\text { protein feed }\end{array}$} & \multirow[b]{2}{*}{$\mathrm{SR}^{1}(\%)$} & \multirow[b]{2}{*}{$\begin{array}{c}\text { Diet } \\
\text { DMI (\%) }\end{array}$} & \multirow{2}{*}{$\begin{array}{c}\text { Milk yield } \\
\text { in control } \\
\text { (kg/day) }\end{array}$} & \multicolumn{4}{|c|}{ Yield $(\%)^{2}$} & \multirow[b]{2}{*}{ Milk urea (\%) } & \multirow[b]{2}{*}{$\mathrm{N}^{3}$} & \multirow[b]{2}{*}{ Ref. $^{4}$} \\
\hline & & & & & & Milk & Lactose & Fat & Protein & & & \\
\hline \multirow[t]{17}{*}{ Cow } & Camelina E & RSM & 100 & -3 & 31 & 4 & 4 & -3 & 1 & -16 & 1 & 1 \\
\hline & Faba bean & RSM & 50 & -3 & 31 to 32 & -2 & -2 & 0 & -4 & 7 & 2 & 2 \\
\hline & Faba bean & RSM & 100 & -4 & 25 to 35 & -6 & -5 & -2 & -7 & 13 & 5 & 2 to 5 \\
\hline & Faba bean & SBM & 40 & $-1^{5}$ & 20 to 22 & 0 & 1 & -3 & -1 & -10 & 2 & 6 \\
\hline & Faba bean & SBM & 100 & -1 & 27 & 0 & 1 & -3 & -1 & -10 & 1 & 7 \\
\hline & Lupin, blue & RSM & 50 & -1 & 31 & -4 & -3 & 0 & -2 & -5 & 1 & 8 \\
\hline & Lupin, blue & RSM & 100 & -4 & 31 to 35 & -6 & -3 & 2 & -6 & 2 & 2 & 4,8 \\
\hline & Lupin, white & SBM & 100 & -1 & 26 to 38 & 0 & 1 & -1 & -3 & 3 & 5 & 9 to 11 \\
\hline & Lupin, yellow & SBM & 100 & -5 & 32 & -6 & -5 & 0 & -9 & $n r^{6}$ & 1 & 12 \\
\hline & Pea & RSM & 50 & -1 & 24 & -2 & -2 & 1 & -3 & 2 & 1 & 13 \\
\hline & Pea & RSM & 100 & -3 & 24 to 25 & -6 & -6 & -5 & -7 & 12 & 2 & 5,13 \\
\hline & Pea & RSM-SBM & 95 & $\mathrm{nr}$ & 32 & -5 & $\mathrm{nr}$ & 6 & -2 & $\mathrm{nr}$ & 1 & 14 \\
\hline & Pea & SBM & 33 to 80 & 4 & 21 to 35 & 2 & 3 & 3 & 4 & 17 & 5 & 15 to 17 \\
\hline & Pea & SBM & 100 & 2 & 21 to 27 & 2 & 3 & 1 & 3 & -2 & 2 & 15,18 \\
\hline & Microalgae & RSM & 50 & -1 & 23 to 31 & 0 & -1 & -1 & 2 & 4 & 3 & 3,19 \\
\hline & Microalgae & RSM & 100 & 0 & 23 to 28 & -3 & -2 & -2 & -1 & 3 & 2 & 19 \\
\hline & Microalgae & SBM & 100 & 0 & 30 & 4 & 4 & 11 & 4 & -8 & 3 & 20 \\
\hline \multirow[t]{7}{*}{ Sheep } & Camelina $\mathrm{E}$ & RSM & 50 to 60 & $\mathrm{nr}$ & 1.2 & 11 & -1 & -6 & -2 & $\mathrm{nr}$ & 2 & 21,23 \\
\hline & Camelina E & RSM & 100 & $\mathrm{nr}$ & 1.2 & 8 & -1 & -14 & -1 & $\mathrm{nr}$ & 1 & 21 \\
\hline & Camelina S & SBM & 50 & -2 & 0.7 to 0.8 & 7 & 8 & 11 & 6 & $\mathrm{nr}$ & 2 & 23 \\
\hline & Faba bean & SBM & 100 & 2 & 0.7 to 0.8 & -1 & 2 & -1 & 2 & $\mathrm{nr}$ & 2 & 24,25 \\
\hline & Lupin, white & SBM & 100 & -5 & 1.4 & 5 & 8 & 3 & 1 & -2 & 1 & 26 \\
\hline & Pea & SBM & 100 & -2 & 0.7 to 0.8 & 9 & 12 & 7 & 4 & -2 & 2 & 24,25 \\
\hline & Pea & SBS-SFM & 100 & -5 & 1.0 & 4 & 3 & 6 & 8 & $\mathrm{nr}$ & 1 & 27 \\
\hline \multirow[t]{2}{*}{ Goat } & Faba bean & $\mathrm{CS}$ & 100 & 0 & 1.1 & -2 & -11 & -11 & 0 & $\mathrm{nr}$ & 1 & 28 \\
\hline & Faba bean & WLS & 100 & 3 & 1.6 & 1 & -2 & -3 & 0 & $\mathrm{nr}$ & 1 & 29 \\
\hline
\end{tabular}

$\mathrm{E}=$ expeller; $\mathrm{S}=$ seed; $\mathrm{DMI}=$ dry matter intake; $\mathrm{CS}=$ cottonseeds; $\mathrm{RSM}=$ rapeseed meal; $\mathrm{SBM}=$ soya bean meal; $\mathrm{SBS}=$ soya bean seeds; $\mathrm{SFM}=$ sunflowerseed meal; WLS = white lupin seeds.

${ }^{1}$ Isonitrogenous substitution rate (SR) of control protein feed by alternative protein feed.

${ }^{2}$ Change (\%) due to alternative protein feed compared to control protein feed.

${ }^{3}$ Number of diet comparisons.

${ }^{4}$ References shown in Supplementary Table S2.

${ }^{5}$ Concentrate intake.

${ }^{6}$ Not reported.

The feasibility of the use of alternative grain legumes in ruminant diets is determined not only by their chemical composition, but also by the rate and extent of degradation of nutrients in the rumen. The degradability of faba bean, pea and lupin protein in the rumen is often over $80 \%$ (Watson et al., 2017) that is significantly higher than those of soya bean or rapeseed expellers. In addition, the heattreatment of faba beans, peas or lupin seeds to lower ruminal degradability has seldom improved animal performance (White et al., 2007; Watson et al., 2017). It is plausible that the high-protein degradability in the rumen together with suboptimal AA profile in the undegraded protein of alternative grain legume seeds limit their production responses in high-yielding ruminants. Faba beans contain also antinutritional factors such as vicine and convicine (Heuzé et al., 2016a), lupins quinolizidine alkaloids (Wasilewko and Buraczewska, 1999) and peas lectins and tannins (Heuzé et al., 2017a). However, ruminants are not susceptible to most of them because of microbial metabolism and degradation in the rumen (Watson et al., 2017).

Replacing protein in soya bean meal partially or completely with faba beans, blue lupin, white lupin or peas has resulted in rather similar bovine lactation performances (Watson et al., 2017; Table 3). Furthermore, the milk fat concentration of medium chain saturates has been lower and those of cis-9 18:1 and 18:2n-6 higher in cows fed white lupins seeds relative to soya bean meal (White et al., 2007). In contrast, the milk production responses of alternative grain legumes are often inferior compared to the rapeseed meal in dairy cow nutrition (Watson et al., 2017; Table 3). Substitution of rapeseed meal with faba beans has typically decreased milk protein yield and increased milk urea concentration and the proportion of $\mathrm{N}$ excreted in urine suggesting less efficient use of protein in faba beans than in rapeseed (Puhakka et al., 2016; Table 3), thus leading to increased $\mathrm{N}$ emissions from animals. 
Table 4 The effect of some alternative feeds on the average daily gains (ADG) of ruminants

\begin{tabular}{|c|c|c|c|c|c|c|c|}
\hline Species & Alternative feed & Control feed & $\mathrm{SR}^{1}(\%)$ & Diet $\mathrm{DMI}^{2}$ & $A D G^{2}$ & Main findings & Ref. $^{3}$ \\
\hline Beef steers & Camelina meal & Soya bean meal & 100 & Dec & - & $\begin{array}{l}\text { Camelina increased plasma } 18: 3 n-3 \text { concentration and lessened the } \\
\text { acute-phase protein reaction }\end{array}$ & 1 \\
\hline Dairy heifers & Camelina meal & $\begin{array}{l}\text { Linseed meal } \\
\text { Distillers dried grains with solubles }\end{array}$ & $\begin{array}{l}100 \\
100\end{array}$ & - & - & $\begin{array}{l}\text { Camelina decreased plasma insulin concentration. Camelina had no } \\
\text { major effect on CP or NDF total tract digestibility or rumen } \\
\text { fermentation except for higher ammonia relative to other } \\
\text { treatments }\end{array}$ & 2 \\
\hline Sheep & Camelina expeller & Rapeseed meal & $\begin{array}{l}50 \\
100\end{array}$ & $\mathrm{nr}$ & $\mathrm{nr}$ & $\begin{array}{l}\text { Camelina increased muscle } t 11 \text { 18:1, c9t11 } 18: 2 \text { and n-3 fatty acid } \\
\text { content, but had no effect on 18:0 or c9 18:1 }\end{array}$ & 3 \\
\hline Beef bulls & Lupin (blue) seeds & $\begin{array}{l}\text { Rapeseed meal } \\
\text { Soya bean meal }\end{array}$ & $\begin{array}{l}100 \\
100\end{array}$ & $\begin{array}{c}\text { Dec } \\
-\end{array}$ & $\begin{array}{c}\text { Dec } \\
-\end{array}$ & $\begin{array}{l}\text { Carcass weight and dressing percentage were the highest for } \\
\text { rapeseed. Protein source had no effect on carcass classification or } \\
\text { gross chemical composition. Muscle fatty acid profile was similar } \\
\text { for lupin and soya bean diets, but on rapeseed diet muscle } c 9 t 11 \\
18: 2 \text { and } 18: 3 n-3 \text { contents were higher }\end{array}$ & 4 \\
\hline Beef bulls & Lupin (white) seeds & Soya bean seeds and meal & 100 & - & - & $\begin{array}{l}\text { Main slaughtering and sectioning characteristics were equal. Lupin } \\
\text { diet reduced fatness. Quality traits of meats were comparable in } \\
\text { terms of colour, tenderness and chemical and fatty acid profile as } \\
\text { well as post slaughtering pH }\end{array}$ & 5 \\
\hline Beef bulls & $\begin{array}{l}\text { Faba bean-cereal silage } \\
\text { Pea-cereal silage }\end{array}$ & Grass silage & $\begin{array}{l}100 \\
100\end{array}$ & - & - & $\begin{array}{l}\text { Replacing grass silage with grain legume-cereal whole crop silages } \\
\text { had no remarkable effect on carcass characteristics, meat quality, } \\
\text { fatty acid profile or sensory score }\end{array}$ & 6 \\
\hline Beef steers & Lupin (white) silage & Grass silage & 100 & - & - & $\begin{array}{l}\text { Carcass merits were equal. Lupin nitrogen degraded faster in the } \\
\text { rumen compared to grass }\end{array}$ & 7 \\
\hline Sheep & $\begin{array}{l}\text { Faba beans } \\
\quad \text { Lupin (white) seeds }\end{array}$ & Soya bean expeller & $\begin{array}{l}100 \\
100\end{array}$ & $\begin{array}{l}\text { Dec } \\
\text { Dec }\end{array}$ & - & $\begin{array}{l}\text { Protein source had no effect on carcass characteristics except for } \\
\text { decreased back fat thickness for faba bean }\end{array}$ & 8 \\
\hline Sheep & Lupin (white) seeds & $\begin{array}{l}\text { Rapeseed meal } \\
\text { Soya bean meal }\end{array}$ & $\begin{array}{l}100 \\
100\end{array}$ & - & - & $\begin{array}{l}\text { Digestibility of CP and energy were higher for lupin than rapeseed } \\
\text { and soya bean }\end{array}$ & 9 \\
\hline Sheep & Peas & Soya bean meal & $\begin{array}{l}45 \\
100\end{array}$ & - & - & $\begin{array}{l}\text { Carcass and meat composition and quality were not affected by } \\
\text { treatments }\end{array}$ & 10 \\
\hline Sheep & Pea silage & Grass silage & 50 & - & Inc & $\begin{array}{l}\text { Lambs offered pea silage low in tannins grew faster, had increased } \\
\text { chop length and improved digestibility of OM and } \mathrm{N} \text { compared to } \\
\text { grass silage as sole forage in the diet }\end{array}$ & 11 \\
\hline Sheep & Seaweed & Soya bean-barley concentrate & 20 & - & - & $\begin{array}{l}\text { Replacing } 20 \% \text { of soya bean-barley concentrate with seaweeds } \\
\text { (Ruppia maritima or Chaetomorpha linum) had no effect on OM or } \\
\text { CP digestibility, nitrogen partitioning or water intake }\end{array}$ & 12 \\
\hline Sheep & Seaweed & Alfalfa hay & $\begin{array}{c}8 \\
13\end{array}$ & $\begin{array}{l}- \\
-\end{array}$ & - & $\begin{array}{l}\text { Dietary supplementation of seaweed (Ulva lactuca) at low level has } \\
\text { no adverse effect on growth of sheep }\end{array}$ & 13 \\
\hline Goat & Jatropha kernel expeller & Soya bean expeller & $\begin{array}{c}50 \\
100\end{array}$ & $\begin{array}{l}\text { Inc } \\
-\end{array}$ & $\begin{array}{l}\text { Inc } \\
-\end{array}$ & $\begin{array}{l}\text { Replacing } 50 \% \text { or } 100 \% \text { of soya bean expeller with fungally } \\
\text { detoxified jatropha kernel expeller had no adverse effects on } \\
\text { blood parameters. Diet with } 1: 1 \text { (w/w) soya bean expeller and } \\
\text { jatropha kernel expeller resulted in highest DM and CP intake and } \\
\text { ADG }\end{array}$ & 14 \\
\hline Sheep & Jatropha expeller & Soya bean meal & 70 & - & - & $\begin{array}{l}\text { Replacing } 70 \% \text { of soya bean meal in concentrate mixture had no } \\
\text { adverse effects on DM intake or ADG of male lambs. The fertility } \\
\text { of rams was slightly improved by jatropha inclusion in the diet }\end{array}$ & 15 \\
\hline
\end{tabular}

$\mathrm{OM}=$ organic matter.

${ }^{1}$ Substitution rate of control feed by alternative feed.

${ }^{2}$ Effect of alternative feed on dry matter intake (DMI) or ADG: Dec = decrease; $-=$ no effect; Inc = increase; $\mathrm{nr}=$ not reported.

${ }^{3}$ References shown in Supplementary Table S3.

Partial or total replacement of soya bean or rapeseed protein by faba beans, lupin seeds or peas has not significantly altered ADG or meat chemical composition in growing sheep or cattle (Table 4). Besides replacing protein in ruminant diets, starchy faba beans and peas (Table 1) and lupins with higher metabolisable energy content than cereals (Watson et al., 2017) have potential in replacing cereals as well. Indeed, the substitution of cereal grains by grain legumes in dairy cow diets generally increases milk production (White et al., 2007; Watson et al., 2017). Furthermore, starch in peas and faba beans has lower degradability in the rumen than cereal starch (Watson et al., 2017) that lowers the risk for acidosis.

\section{Biorefining of forage crops}

Interest in using grass biomass as a raw material for green biorefineries has arisen recently (McEniry and O'Kiely, 2014; Hermansen et al., 2017). Grass is effective in converting solar radiation into chemical forms of energy and it grows well in humid temperate areas with a capacity for higher biomass and CP production compared to most annual crops (Table 2).
Further, existing technology is available for its cultivation, harvesting and ensiling (Wilkinson and Rinne, 2018). When preserved as silage, the grass biomass can be refined all year round although losses in the protein and water soluble carbohydrates will take place during the fermentation process compared to the parent herbage.

Typically the first step in a green biorefinery process is liquid-solid separation resulting in a liquid fraction containing the soluble components of grass and a fibrous solid fraction. The yield of the fractions depends on the technical solutions of the process, but it is also greatly affected by the raw material characteristics. The ensiling process can even serve as a pretreatment for the biorefinery process, and it may be further improved by using fibrolytic enzymes at the time of harvest as it has increased the liquid yield (Rinne et al., 2017). In the simplest approach, grass juice can be used as a liquid feed to enrich the diet with highly nutritive forage-based component and it is readily consumed by dairy cows and monogastric animals (Rinne et al., 2018), or the fibre fraction can be used as a feed for ruminants (Savonen et al., 2018). Grass fibre is less lignified than, for example, 


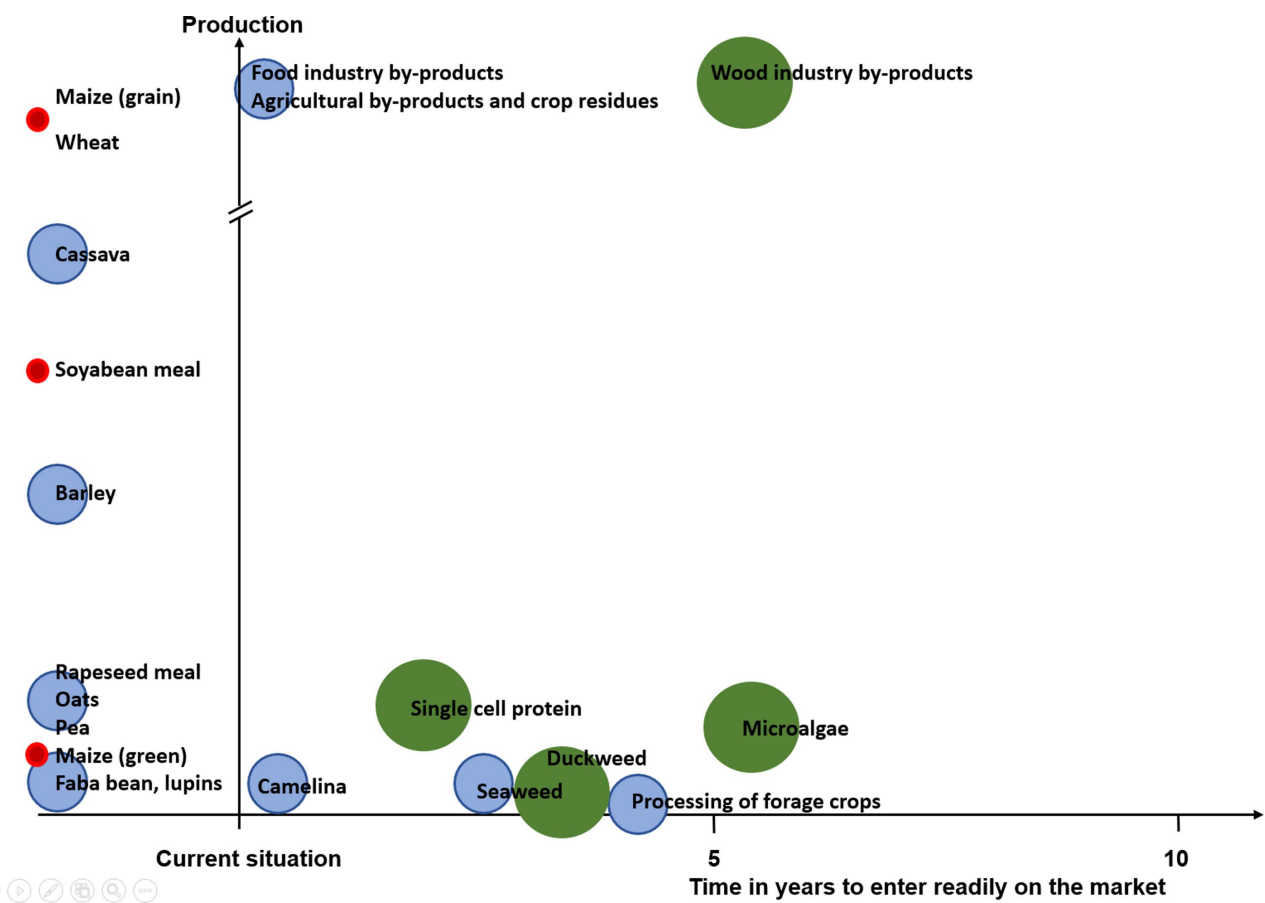

Figure 1 Rough overview of some feeds for ruminants with respect to time to enter readily on the market, extent of production today and potential to increase utilisation in ruminant nutrition sustainably in future (small red bubble=limited; medium-sized blue bubble=moderate; large green bubble = high). Data adapted in part from FAOSTAT (2016), Kruus and Hakala (2016) and USDA (2016).

woods and straw, and milder processes can be used to hydrolyse it (Niemi et al., 2017). The hydrolysed sugars can further be used for a variety of purposes including direct use as feeds, and as substrates for lactic acid fermentation or SCP production. Green biorefineries have potential to improve local nutrient self-sufficiency, provide new business opportunities for rural communities and to produce ecosystem services such as improved soil structure, carbon sequestration and biodiversity. The high costs related to transportation and processing have to date prevented the development of commercial green biorefineries on a large scale (Xiu and Shahbazi, 2015).

\section{Intensive and extensive ruminant production in the temperate zones: fibrous feeds}

\section{Grain legumes as forage}

Harvesting grain legume stands as whole crop silage enables the utilisation of nutrients in stems and leaves as well and extending the cultivation in areas where the length of growing season may limit complete seed ripening. Although yield potential and organic matter digestibility (OMD) of grain legume stands are high (Rinne et al., 2014; Table 2), data on the effects of grain legume whole crop silages on ruminant performance and product quality is limited. In milk production, white lupin silage resulted in lower total DM intakes, but almost similar bovine lactation performance to maize silage as basal forage (Kochapakdee et al., 2004). In meat production, animal performance has been similar or better when white lupin or pea silages have replaced partially or completely grass silage in cattle or sheep diets
(Table 4). Due to their lower fibre concentration relative to grass silage, legume silages may lower ruminal methane emissions (Hristov et al., 2013).

Compared to sole cropping, the bi-cropping of grain legumes and cereals may enhance and stabilise DM yields, reduce weeds and plant diseases and improve $\mathrm{N}$-fixation (Hauggaard-Nielsen et al., 2008). As a forage, grain legume-cereal crop mixtures complement the nutritive value of each other providing an appropriate balance between readily fermentable nutrients and $\mathrm{N}$ in the rumen (Watson et al., 2017). Replacing half of the grass silage DM with faba bean-wheat silage had no effect on DM intake or bovine milk, fat and protein yields or feed $\mathrm{N}$ conversion efficiency to milk protein (Lamminen et al., 2015). Whole crop faba bean-wheat or pea-wheat silages have successfully replaced grass silage in beef production as well (Table 4). Due to the lower costs of $\mathrm{N}$ fertilisers and good yield potential, grain legume silages seem to provide a viable alternative for maize and grass silages both in the intensive and extensive production systems (Table 2). The feeding value and ruminal methane emissions of diets containing forage legumes (lucerne, clovers) have been reviewed elsewhere (Dewhurst, 2013).

\section{Temperate wood-derived products}

Wood is the most abundant source of carbohydrates worldwide. Principal components of wood are cellulose (400 to $450 \mathrm{~g} / \mathrm{kg} \mathrm{DM}$ ) and hemicelluloses (200 to $300 \mathrm{~g} / \mathrm{kg} D M$, Sjöström, 1993). Agroforestry approaches in ruminant nutrition are less common in the temperate areas compared to the tropics or the Mediterranean area. There are, however, 
some applications where, for example, willow (Salix sp.) production for wood chips and the grazing of ruminants are combined to provide additional benefits such as improved microclimate for the animals, self-medication and soil carbon sequestration, although the potential of the untreated woodbased materials to provide energy and nutrients to highyielding dairy cows is limited (Smith et al., 2012 and 2014). Indeed, the in vitro digestibility of DM of untreated wood of various tree species was poor with a range from 0.002 to 0.035 (Millett et al., 1970).

A variety of technologies have been used over decades to improve the digestibility of wood-derived lingo-cellulosic materials. The key is to break the link between the lignin and the cell wall carbohydrates, particularly hemicelluloses, in order to improve the digestibility of ligno-cellulose by rumen microbes. Most pulping and papermaking residues have undergone at least partial delignification. Depending on the process, the residue may contain different proportions of hemicellulose and/or cellulose with or without lignin. The digestibility of pure cellulose is rather high and corresponds to the digestibility of typical ruminant feeds such as cereal grains and good quality forages. Saarinen et al. (1959) determined the in vivo digestibility of 40 wood pulps produced by various pulping methods and reported a range in digestibility from 0.27 to 0.90 depending on the lignin content. The in vivo digestibility of bleached (lignin erased and the pulp whitened) chemical pulp fines from mixed hardwood was 0.78 for DM and 0.86 for carbohydrates (Millett et al., 1973), indicating that the materials have a high energy value for ruminants.

Although wood-derived cellulose can be used as a feed for ruminants, it has higher value as, for example, paper raw material. In contrast, hemicelluloses are a by-product of pulping that are typically burned, and interest of using them as feeds has arisen. Hemicelluloses are not homogeneous compounds but a group of mixed polysaccharides. They can be divided into four groups according to their main type of sugars: xylans, xyloglucans, mannans and $\beta$-glucans. Spruce (Picea sp.) and pine (Pinus sp.; softwood) contain somewhat less hemicelluloses than birch (Betula sp.; hardwood) and hemicellulose composition differs between species (Saarinen et al., 1959). Glucomannans and galactomannans are the principal hemicelluloses of coniferous trees (spruce and pine) and xylans in deciduous trees (birch) while $\beta$-glucans are restricted to grasses.

Hemicelluloses in a liquid form are often called wood molasses or wood sugar concentrates. They have successfully been used as diet components for ruminants at up to $10 \%$ of DM intake (Zinn et al., 1990 and 1993; Herrick et al., 2012). An in vitro gas production experiment revealed that hot water and pressure extracted galactoglucomannan and xylan were readily used as fermentation substrates by rumen microbes of dairy cows fed a grass silage and cereal based diet but arabinogalactan was not (Rinne et al., 2016). In an in vivo digestibility trial, the OMD of the hot water and pressure extracted galactoglucomannan was 0.591 (Rinne et al., 2016).

Bark is another component of wood that has limited value in the pulp and sawmill industry. Although wild ruminants consume bark voluntarily, the energy value of it is so low that incorporating it into dairy cow diets resulted in the reduction of milk production (P. Kairenius et al., unpublished results). Thus, some processing would be needed to improve the digestibility of bark. Wood-derived feeds typically have very low $\mathrm{N}$ and $\mathrm{P}$ concentrations. If the basal diet were high in these nutrients, wood-derived feeds could dilute diets and subsequently increase, for example, the $\mathrm{N}$ use efficiency of lactating dairy cows as it is mainly determined by $\mathrm{N}$ intake (Huhtanen et al., 2008). Wood-derived feeds may also provide a source of feed in the case of lack of other feeds, for example, in crisis situations. In general, they may fit best in the diets of animals with low-energy requirements rather than in dairy cow diets in the intensive production systems.

\section{Extensive ruminant production in the tropics: protein supplements}

Fodder trees and shrubs

Low-quality forages such as rice (Oryza sativa) straw and pangola (Digitaria eriantha) grass low in protein and high in NDF and ADF are common in ruminant nutrition in the tropics $(42,691$ and $424 \mathrm{~g} / \mathrm{kg}$ DM for rice straw (Heuzé and Tran, $2015 \mathrm{~b}$ ) and 5 to 12,610 to 790 and 350 to $420 \mathrm{~g} / \mathrm{kg}$ DM for pangola grass (Tikam et al., 2013), respectively). Thus, the

Table 5 Effect of using tropical fodder tree and shrubs supplementation on feed intake, rumen volatile fatty acid production and milk yield in ruminants fed rice straw based diets

\begin{tabular}{|c|c|c|c|c|c|c|c|c|c|c|}
\hline \multirow[b]{2}{*}{ Supplement } & \multirow[b]{2}{*}{ Form } & \multirow[b]{2}{*}{ Dose (kg/day) } & \multirow[b]{2}{*}{ Species } & \multirow[b]{2}{*}{ DM intake } & \multicolumn{4}{|c|}{ Rumen fermentation } & \multirow[b]{2}{*}{ Milk yield } & \multirow[b]{2}{*}{ Ref. } \\
\hline & & & & & TVFA & $C_{2}$ & $C_{3}$ & $\mathrm{C}_{4}$ & & \\
\hline \multirow[t]{2}{*}{ Cassava } & Hay & 2.0 & Dairy cow & Inc & Inc & Dec & Inc & Dec & Inc & 1 \\
\hline & Silage & 2.5 & Dairy cow & Inc & Inc & Dec & Inc & - & Inc & 2 \\
\hline \multirow[t]{2}{*}{ Leucaena } & Silage & RLS60 & Dairy steer & Inc & Inc & Dec & Inc & - & & 3 \\
\hline & Hay & 6.0 & Buffaloes & - & Inc & Dec & Inc & - & & 4 \\
\hline Flemingia & Hay & $\mathrm{FHM}+\mathrm{CH}$ & Dairy steer & - & - & Dec & Inc & Dec & & 5 \\
\hline
\end{tabular}

$\mathrm{DM}=$ dry matter; TVFA = total volatile fatty acids; $\mathrm{C}_{2}=$ acetate; $\mathrm{C}_{3}=$ propionate; $\mathrm{C}_{4}=$ butyrate; Dec $=$ decrease; $-=$ no effect; Inc $=$ increase; $\mathrm{RLS} 60=40 \%$ rice straw $+60 \%$ leucaena silage fed ad libitum; $\mathrm{FHM}+\mathrm{CH}=75 \mathrm{~g}$ flemingia hay meal $+75 \mathrm{~g}$ cassava hay.

${ }^{1}$ References shown in Supplementary Table S5 
basal diet is typically much lower in protein and higher in fibre compared to that used in the intensive ruminant production of the temperate zones. In Asian tropics, rice straw is commonly supplemented with cassava (Manihot esculenta) chip rich in soluble carbohydrates but poor in CP (750 to $850 \mathrm{~g} / \mathrm{kg} \mathrm{DM}$ and 20 to $30 \mathrm{~g} / \mathrm{kg} \mathrm{DM}$, respectively; Wanapat and Kang, 2015) and soya bean meal. However, the high price of soya bean meal limits its use in smallholder farming.

Leaves of local fodder trees and shrubs such as cassava, leuceana (Leucaena leucocephala), moringa (Moringa oleifera) and sesbania (Sesbania sesban) often contain almost as much CP as NDF (Table 1), the concentration of former being roughly half of that in soya bean meal. Supplementing the rice straw-based diets with these alternative protein sources increases DM intake, improves microbial protein synthesis in the rumen and the efficiency of rumen fermentation with a shift towards propionate (Table 5; Supplementary Table S4), thus potentially mitigating methane production. These beneficial changes may be due to certain natural secondary compounds present in these alternative feeds, namely condensed tannins and saponins (Wanapat et al., 2013).

Combined food-feed production system to provide a year round feeding calendar and to enrich smallholder farming environment is illustrated in Supplementary Figure S1. Under the proposed system, two grass types with (a) erect and tall growth habit and (b) semi-prostrate or prostrate growth habit are used to maximise the biomass production under zero-grazing and grazing, respectively. Roots from cassava can be utilised as a carbohydrate source while the whole top is dried to provide protein (Wanapat, 2009; Wanapat et al., 2017). In addition, the leaves of fodder trees and shrubs such as leguminous leucaena, flemingia (Flemingia macrophylla), and moringa are harvested in intervals and used fresh or preserved for later use. The intercropping of cassava with leguminous crops, for example, common bean (Phaseolus calcaratus) and cowpea (Vigna unguiculata), has potential to improve soil fertility and to increase biomass yield (Wanapat, 2009; Wanapat et al., 2017). Crop residues such as rice straw, corn stover and sugar cane top are also exploited in ruminant feeding.

\section{Jatrophas}

Jatrophas are drought-resistant shrubs or small trees native to American tropics and widely distributed in the tropical and subtropical regions around the world. Jatropha genus includes more than 175 species, Jatropha curcas being one of the most studied species in animal feeding. Jatropha is an interesting biofuel crop due to the high EE concentration of its kernels (570 to $600 \mathrm{~g} / \mathrm{kg} \mathrm{DM}$; Makkar et al., 2012), and the de-fatted kernel residue, jatropha kernel meal, is a good source of nutrients with CP concentration of 620 to $770 \mathrm{~g} / \mathrm{kg}$ DM (Table 1). In comparison to soya bean protein, jatropha is deficient in lysine, but richer in other essential AA (Table 1; Makkar et al., 2012).

The majority of jatropha species are highly toxic to both ruminants and monogastrics due to phorbol esters (1 to $3 \mathrm{mg} / \mathrm{g}$ kernel meal; Makkar et al., 2012), but they can successfully be detoxified. The complete detoxification is absolutely necessary to avoid animal mortality (Elangovan et al., 2013). In addition, the high concentration of antinutritional factors (trypsin inhibitors, lectin and phytate) may limit the use of jatropha especially for monogastrics unless deactivated by heat treatment and supplemented with phytase enzyme. When completely detoxified, the substitution of soya bean by jatropha has not impaired the DM intake or ADG of sheep and goats (Table 4). Though the yield potential is high (Table 2), the inconsistency of yields of current cultivars is the major restriction for the spread (Heuzé et al., 2016b).

\section{All production systems of ruminants worldwide: alternative protein and fibrous feeds}

The major advantages of SCP, seaweed and duckweed are the independence of production from arable land and of weather conditions as well as the high and continuous harvests (Nasseri et al., 2011; van der Spiegel et al., 2013; Table 2). However, cultivation, harvesting, preservation (especially drying) and application in feed in a large scale needs further research (van Krimpen et al., 2013) to lower the production cost of these novel feeds to competitive level. In the long-term, microalgae and duckweed have perhaps the greatest potential to become viable local protein and fibre sources for ruminants worldwide (Table 2; Figure 1).

\section{Single-cell protein}

Single-cell protein consists of microbial cells from yeast, bacteria, fungi or microalgae. These micro-organisms can utilise a wide variety of inexpensive feedstocks and wastes as sources of carbon, nutrients and energy for growth to produce biomass rich in protein. The protein content of SCP varies due to culture conditions, species and strains (Lindberg et al., 2016) but is in the same order as in soya bean expeller (Table 1). The major constraints are the risk for allergens and the accumulation of heavy metals, pesticides and toxins especially if grown on polluted and contaminated substrates, generally high-nucleic acid content (bacteria and yeasts $>$ fungi > microalgae; 60 to 120,70 to 100,30 to $80 \mathrm{~g} / \mathrm{kg}$ DM, respectively) and economical and efficient mass-scale production and harvesting (Nasseri et al., 2011; Lindberg et al., 2016). Dietary nucleic acids and their derivatives are rapidly degraded in the rumen and certain end-products can be re-used as sources of carbon and $\mathrm{N}$ for bacterial growth (McAllan, 1982), but the $\mathrm{N}$ in nucleic acids is not as easily available as that of true protein or ammonia.

The basic stages of SCP production process include (a) medium preparation, (b) fermentation or photosynthesis and (c) harvesting and downstream processing like washing, cell disruption, protein extraction and purification (Ravindra, 2000). The SCP concept was introduced already during the First World War primarily as a human food (Lindberg et al., 2016). However, the higher production costs of SCP linked to challenges in efficient and economical cell recovery in relation 
to more conventional foods and feeds is perhaps the main reason why SCP has not reached widespread commercial use so far. Established processes include the use of yeasts Candida lipolytica and Candida tropicalis with alkanes as substrate (product called Toprina), bacterium Methylophilus methtlotrophus with methane as substrate, bacterium Pseudomonas methylotrophus (Pruteen) with methanol as substrate, filamentous fungus Peacilomyces variotii grown on sulphite spent liquor of forest industry sidestream (Pekilo) and yeast Kluveromyces marxianus grown on whey (Nasseri et al., 2011). The reasons why the SCP concept could become more common and economically viable in future are the rising ecoawareness and the need to intensify nutrient and resource utilisation combined with the sharp price rises caused by the prospect of protein scarcity (Lindberg et al., 2016).

\section{Microalgae}

Microalgae are a diverse group of unicellular or simple multicellular microorganisms with widely varying nutritive composition (Table 1). As animal feed, microalgae have several potential uses. Species high in lipids, such as 22:6n-3-enriched Schizochytrium sp., can be used to modify ovine (Bichi et al., 2013) or bovine (Boeckaert et al., 2008) milk fat healthier for humans in terms of increased trans-11 18:1, cis-9, trans-11 18:2 and n-3 content. Algal 22:6n-3 supplementation has increased also the $\mathrm{n}-3$ content of ruminant meat (Meale et al., 2014), but no effects were found on methane production (Moate et al., 2013). In turn, microalgae or defatted microalgae residues high in CP (e.g. Spirulina platensis and Chlorella vulgaris), or high in carbohydrates can substitute conventional protein (Lamminen et al., 2017) or energy feeds (van Emon et al., 2015), respectively.

The AA composition of microalgae generally compares favourably to soya bean meal (Becker, 2013) and rapeseed meal (Feedipedia, 2018; Luke, 2018), but may vary significantly between species (Table 1). However, in comparison to rapeseed meal and soya bean meal, microalgae protein is often lower in histidine, which is typically the first AA limiting milk production on grass silage and cereal-based diets (e.g. Vanhatalo et al., 1999). The protein degradability of many microalgae species is suggested to be higher than that of rapeseed (Costa et al., 2016; Lamminen et al., 2017), soya bean and cottonseed meals (Costa et al., 2016), but this can possibly be affected by the growing and harvesting conditions of microalgae (Lodge-Ivey et al., 2014). Compared to the conventional protein or energy feeds, large doses of microalgae or defatted microalgae residue may impact negatively on feed intake of ruminants depending on microalgae composition (van Emon et al., 2015; Costa et al., 2016; Lamminen et al., 2016 and 2017). The palatability of microalgae can possibly be improved by feed processing, for example, pelleting (Hintz et al., 1966). Compared to rapeseed meal, microalgae have not affected milk yield, but decreased the milk protein yield of dairy cows in late lactation, which together with decreasing $\mathrm{N}$ utilisation for milk production suggests that the protein value of microalgae is possibly slightly lower than that of rapeseed meal
(Lamminen et al., 2017), but similar to soya bean protein (Table 3).

The local on-farm production of microalgae in ponds or in closed photoreactors connected to animal drinking water system could lower the energy inputs of feed drying, preservation and transportation making microalgae cultivation in future a viable concept also in the extensive farming. Indeed, microalgae have successively been distributed through drinking water (Panjaitan et al., 2010) to growing cattle grazing low quality grasses to improve microbial protein production in the rumen and diet digestibility (Panjaitan et al., 2015). In addition, microalgal-derived renewable biofuels have high potential to replace fossil fuels of diminishing reserves in future. The cost for the biofuels production from microalgae is not yet competitive with fossil fuels, but with advancing technologies and possible government incentives it may soon become profitable (Milano et al., 2016) thus providing defatted microalgae residues for livestock in a mass-scale.

\section{Seaweeds}

Seaweeds are complex multicellular organisms growing in salt water or a littoral zone of marine environment (van der Spiegel et al., 2013). They can be of many different shapes, sizes, colours and composition. Fresh seaweed contains very large amounts of water ( 700 to $900 \mathrm{~g} / \mathrm{kg} \mathrm{DM}$ ) and needs to be consumed quickly or preserved by, for example, drying or ensiling. Brown algae (Phaeophyceae) are of lesser nutritional value than red (Rhodophyceae) and green algae (Chlorophyceae) due to lower CP content (up to $140 \mathrm{v}$. up to 500 and $300 \mathrm{~g} / \mathrm{kg} \mathrm{DM}$, respectively). The protein content of marine seaweeds varies between seasons, but in situ rumen degradable protein remains unaffected with high inherent variability between algal species ( $24 \%$ to $51 \%$ of CP; Tayyab et al., 2016). Protein in all seaweeds is typically deficient in essential AA except for methionine (Makkar et al., 2016; Table 1).

Seaweeds are low in cellulose (about $40 \mathrm{~g} / \mathrm{kg}$ DM) but rich in specific complex carbohydrates (e.g. alginate, laminarin and fucoidan). Step-wise increase in the levels of seaweeds in the diet may enable rumen microbes to adapt and utilise these compounds (Makkar et al., 2016). Seaweeds concentrate heavy metals and minerals from seawater and contain several times the ash content of land plants that limits their gross energy value and requires regular monitoring (van der Spiegel et al., 2013; Makkar et al., 2016).

Makkar et al. (2016) have recently reviewed in detail the nutritive value of seaweed indicating that some species have the potential to contribute to the protein and energy needs of ruminants (e.g. Macrocystis pyrifera, Palmaria palmatata, Laminaria digitata, Ulva lactuca), while others contain a number of bioactive compounds, which could be used as prebiotics for enhancing production and health status of animals (e.g. Ascophyllum nodosum). Moreover, some seaweed species have shown potential to mitigate ruminal methane production in vitro depending on the basal diet (Maia et al., 2016). The seaweeds used for animal feeding 
can be cultivated or harvested in the wild (Table 4; Makkar et al., 2016; Tayyab et al., 2016) serving to mitigate nutrient loading and to counteract eutrophication processes (Lindberg et al., 2016). However, high collection rates in the wild have impaired the equilibrium of coastal ecosystems (Makkar et al., 2016). In addition, increased cultivation of seaweeds may promote increased production of bromoform, a metabolic by-product of seaweeds that causes the depletion of atmospheric ozone layer (Carpenter and Liss, 2000).

\section{Duckweeds}

Duckweeds are monocotyledonous, small floating plants with no stems or true leaves of the botanical family Lemnaceae comprising of four genera (Lemna, Spirodela, Wolffia and Wolfiella). Duckweeds are found worldwide, but they grow best in stagnant water between $17.5^{\circ} \mathrm{C}$ and $30^{\circ} \mathrm{C}$ (Heuzé and Tran, 2015a) and may have a 50\% biomass increase every two days (van Krimpen et al., 2013). Thus, duckweed is a potential novel nutrient source for herbivores worldwide. Only few studies have been performed on duckweed in ruminants (van der Spiegel et al., 2013). Overall, duckweed is consumed well in both dried and fresh forms (Heuzé and Tran, 2015a) and it can supply a significant proportion of protein and other nutrients to animals with no significant adverse effects on performance (Cheng and Stomp, 2009; Zetina-Cordoba et al., 2013).

The duckweed protein is much lower in essential AA histidine, methionine and lysine compared to that of soya bean and rapeseed expeller (Table 1) that may limit duckweed's production responses relative to them. Estimates of ruminal protein degradability vary widely between $50 \%$ and $80 \%$ (Heuzé and Tran, 2015a). Duckweed contains significant amounts of ash and NDF (Table 1), but has low-lignin content $(57 \mathrm{~g} / \mathrm{kg} \mathrm{DM}$; Heuzé and Tran, 2015a). It has therefore potential to substitute also forage (Zetina-Cordoba et al., 2013) and minerals (particularly P; van der Spiegel et al., 2013) in ruminant diets. Nevertheless, high oxalic acid content may restrict the use of duckweed for livestock (van der Spiegel et al., 2013).

Similarly to microalgae, local on-farm production of duckweed, for example, in ponds may offer a viable concept for ruminant feed production in future. Nutrient scavenging from field runoffs, manure and greywater by duckweeds has potential to reinforce circular economy practices at farm level and to decrease the environmental footprint of ruminantbased food production systems. The very high growth rate (van Krimpen et al., 2013) enables that duckweed could be regularly harvested and fed to animals as fresh. Feeding fresh duckweed also limits the costs related to drying and preservation on-farm. Due to much bigger particle size relative to microalgae, simple mechanical harvesting of duckweed is feasible.

\section{Conclusions}

In the short term, the seeds and whole crop forages of $\mathrm{N}$-fixing grain legumes as well as by-products from food and biofuel industries have the greatest potential to replace or supplement traditional crops in ruminant rations in the intensive and extensive production systems in the temperate zones (summarising Figure 1). Lipid-rich camelina expeller, as an example, beneficially modifies the fatty acid composition of ruminant products with potential to mitigate simultaneously enteric methane formation, whereas the oil fraction of seeds could be used as an on-farm biofuel to increase the energy independence of farmers. In the tropics, the leaves of fodder trees and shrubs (e.g. cassava, Leucaena sp., Flemingia sp.) are good protein supplements for ruminants especially in the extensive production systems where the potential to improve diet digestibility and to mitigate enteric methane emissions is the highest. Combined foodfeed production system to improve animal productivity and the efficiency of nutrient recycling as well as to decrease footprint on environment is recommended to smallholders (summarising Supplementary Figure S1), whereas detoxified jatropha meals could be suited for larger-scale feed and animal production in the tropics.

In the long term, microalgae and duckweed of high-yield potentials may become economically competitive local protein and fibre sources, respectively, for ruminants worldwide (Figure 1). This is due to the independence of their production from arable land and weather conditions while animal performance and product quality remain comparable to the traditional feeds. Microalgal derived renewable biofuels have a high potential to replace fossil fuels of diminishing reserves in future, thus providing defatted microalgae residues for intensive livestock farming in a mass-scale. Furthermore, onfarm production of microalgae connected to animal drinking water system could lower energy inputs of feed drying, preservation and transportation making microalgae competitive feed ingredient also in extensive farming. Exploitation of vast nutrient reserves in forests both in the temperate and tropical zones warrants further research on their feed value, the breaking of lignin-linkages of wood material and subsequent animal production responses.

Under the climatic conditions changing at an accelerating pace, the ruminant-based livestock systems in both temperate and tropical environments are very flexible in the types of biomasses that can be used as feeds. Despite the environmental footprint of ruminants, their importance in food production system cannot be ignored because of their unique ability to naturally consume fibrous vegetable material not exploitable to humans and other monogastrics and convert it to milk and meat of high nutritive value. Transition to ruminant diets comprising fibrous feed sources supplemented exclusively on alternative and novel feeds has great potential to improve sustainability of ruminant-derived food production, which will not compete with human-edible food materials.

\section{Acknowledgements}

This review is presented in The International Symposium on the Nutrition of Herbivores (ISNH) 2018 in Clermont-Ferrand, France. The authors thank organising committee for the invitation. 


\section{Supplementary material}

To view supplementary material for this article, please visit https://doi.org/10.1017/S1751731118002252

\section{References}

Arco-Pérez A, Ramos-Morales E, Yáñez-Ruiz DR, Abecia L and Martín-García Al 2017. Nutritive evaluation and milk quality of including of tomato or olive byproducts silages with sunflower oil in the diet of dairy goats. Animal Feed Science and Technology 232, 57-70.

Bayat AR, Kairenius $P$, Stefański T, Leskinen $H$, Comtet-Marre S, Forano $E$, Chaucheyras-Durand F and Shingfield KJ 2015. Effect of camelina oil or live yeasts (Saccharomyces cerevisiae) on ruminal methane production, rumen fermentation, and milk fatty acid composition in lactating cows fed grass silage diets. Journal of Dairy Science 98, 3166-3181.

Becker EW 2013. Microalgae for human and animal nutrition. In Handbook of microalgal culture: applied phycology and biotechnology (2nd edition, ed. A Richmond and Q Hu), pp. 461-503. Wiley-Blackwell, Chicester, UK.

Bichi E, Hervás G, Toral PG, Loor JJ and Frutos P 2013. Milk fat depression induced by dietary marine algae in dairy ewes: persistency of milk fatty acid composition and animal performance responses. Journal of Dairy Science 96, 524-532.

Boeckaert C, Vlaeminck B, Dijkstra J, Issa-Zacharia A, Van Nespen T, Van Straalen W and Fievez V 2008. Effect of dietary starch or micro algae supplementation on rumen fermentation and milk fatty acid composition of dairy cows. Journal of Dairy Science 91, 4714-4727.

Cais-Sokolińska D, Pikul J, Wójtowski J, Danków R, Teichert J, CzyżakRunowska $G$ and Bagnicka E 2015. Evaluation of quality of kefir from milk obtained from goats supplemented with a diet rich in bioactive compounds. Journal of the Science of Food and Agriculture 95, 1343-1349.

Carpenter LJ and Liss PS 2000. On temperate sources of bromoform and other reactive organic bromine gases. Journal of Geophysical Research 105, 2053920547.

Cheng JJ and Stomp AM 2009. Growing duckweed to recover nutrients from wastewaters and for production of fuel ethanol and animal feed. Clean-Soil, Air, Water 37, 17-26.

Coskun D, Britto DT, Shi W and Kronzucker HJ 2017. Nitrogen transformations in modern agriculture and the role of biological nitrification inhibition. Nature Plants 3, 17074

Costa DFA, Quigley SP, Isherwood P, McLennan SR and Poppi D 2016. Supplementation of cattle fed tropical grasses with microalgae increases microbial protein production and average daily gain. Journal of Animal Science 94, 20472058.

Dewhurst RJ 2013. Milk production from silage: comparison of grass, legume and maize silages and their mixtures. Agricultural and Food Science 22, 57-69.

Elangovan AV, Gowda NKS, Satyanarayana ML, Suganthi RU, Rao SBN and Sridhar M 2013. Jatropha (Jatropha curcas) seed cake as feed ingredient in the rations of sheep. Animal Nutrition and Feed Technology 13, 57-67.

FAOSTAT 2016. Food and agriculture data. Retrieved on 22 April 2018 from http://www.fao.org/faostat/en/\#home.

Feedipedia 2018. Animal Feed Resources Information System. Retrieved on 27 April 2018 from http://www.feedipedia.org/.

Halmemies-Beauchet-Filleau A, Kokkonen T, Lampi AM, Toivonen V, Shingfield $\mathrm{KJ}$ and Vanhatalo A 2011. Effect of plant oils and camelina expeller on milk fatty acid composition in lactating cows fed diets based on red clover silage. Journal of Dairy Science 94, 4413-4430.

Halmemies-Beauchet-Filleau A, Shingfield KJ, Simpura I, Kokkonen T, Jaakkola S, Toivonen V and Vanhatalo A 2017. Effect of incremental amounts of camelina oil on milk fatty acid composition in lactating cows fed diets based on a mixture of grass and red clover silage and concentrates containing camelina expeller. Journal of Dairy Science 100, 305-324.

Hauggaard-Nielsen H, Jørnsgaard B, Kinane J and Jensen E 2008. Grain legumecereal intercropping: the practical application of diversity, competition and facilitation in arable and organic cropping systems. Renewable Agriculture and Food Systems 23, 3-12.

Hermansen JE, Jørgensen U, Lærke PE, Manevski K, Boelt B, Jensen SK, Weisbjerg MR, Dalsgard TK, Danielsen M, Asp T, Amby-Jensen M, Sorensen CA.G, Jensen
MV, Gylling M, Leindedam J, Lübeck M and Fog E 2017. Green biomass - protein production through bio-refining. DCA Report No. 093. Aarhus University, Denmark. 68 p. Retrieved on 25 November 2017 from www.dca.au.dk.

Herrero $\mathrm{M}$, Henderson $\mathrm{B}$, Havlík $\mathrm{P}$, Thornton PK, Conant RT, Smith $\mathrm{P}$, Wirsenius S, Hristov AN, Gerber P, Gill M, Butterbach-Bahl K, Valin H, Garnett T and Stehfest $\mathrm{E}$ 2016. Greenhouse gas mitigation potentials in the livestock sector. Nature Climate Change 6, 452-461.

Herrick KJ, Hippen AR, Kalscheur KF, Anderson JL, Ranatunga SD, Patton RS and Abdullah M 2012. Lactation performance and digestibility of forages and diets in dairy cows fed a hemicellulose extract. Journal of Dairy Science 95, 3342-3353. Heuzé V and Tran G 2015a. Duckweed. Retrieved on 26 July 2017 from https:// www.feedipedia.org/node/15306.

Heuzé V and Tran G 2015b. Rice straw. Retrieved on 15 December 2017 from https://feedipedia.org/node/557.

Heuzé V, Tran G, Delagarde R, Lessire M and Lebas F 2016a. Faba bean (Vicia faba). Retrieved on 26 July 2017 from http://www.feedipedia.org/node/4926.

Heuzé V, Tran G, Edouard N, Renaudeau D, Bastianelli D and Lebas F 2016b. Jatropha (Jatropha sp.) kernel meal and other jatropha products. Retrieved on 23 April 2018 from https://www.feedipedia.org/node/620.

Heuzé V, Tran G, Giger-Reverdin S, Noblet J, Renaudeau D, Lessire M and Lebas F 2017a. Pea seeds. Retrieved on 26 July 2017 from http://www.feedipedia.org/ node/264.

Heuzé V, Tran G and Lebas F 2017b. Camelina (Camelina sativa) seeds and oil meal. Retrieved on 26 July 2017 from http://www.feedipedia.org/node/4254.

Hintz HF, Heitman H, Weir WC, Torell DT and Meyer JH 1966. Nutritive value of algae grown on sewage. Journal of Animal Science 25, 675-681.

Hristov AN, Oh J, Firkins JL, Dijkstra J, Kebreab E, Waghorn G, Makkar HPS, Adesogan AT, Yang W, Lee C, Gerber PJ, Henderson B and Tricarico JM 2013. Special topics - mitigation of methane and nitrous oxide emissions from animal operations: I. A review of enteric methane mitigation options. Journal of Animal Science 91, 5045-5069.

Huhtanen P, Nousiainen J, Rinne M, Kytölä K and Khalili H 2008. Utilization and partition of dietary nitrogen in dairy cows fed grass silage-based diets. Journal of Dairy Science 91, 3589-3599.

Keske CM, Hoag DL, Brandess A and Johnson JJ 2013. Is it economically feasible for farmers to grow their own fuel? A study of Camelina sativa produced in the western United States as an on-farm biofuel. Biomass and Bioenergy 54, 89-99. Knapp JR, Laur GL, Vadas PA, Weiss WP and Tricarico JM 2014. Invited review: enteric methane in dairy cattle production: quantifying the opportunities and impact of reducing emissions. Journal of Dairy Science 97, 3231-3261.

Kochapakdee S, Moss BR, Lin J, Reeves DW, McElhenney WH, Mask P and Santen EV 2004. Evaluation of white lupin, temperate corn, tropical corn, and hybrid pearl millet silage for lactating cows. In Proceedings of the 10th International Lupin Conference, Wild and Cultivated Lupins from the Tropics to the Poles, 19-24 June 2002, Laugarvatn, Iceland, pp. 300-307.

Kruus $\mathrm{K}$ and Hakala T 2016. The making of bioeconomy transformation. VTT Technicak Research Centre of Finland Ltd. Retrieved on 15 November 2017 from https://makingoftomorrow.com/wp-content/uploads/2017/02/The-Makingof-Bioeconomy-Transformation-2017.pdf.

Lamminen $M$, Halmemies-Beauchet-Filleau A, Kokkonen T, Jaakkola $S$ and Vanhatalo A 2016. Microalgae as a substitute for soya bean meal in the grass silage based dairy cow diets. In Proceedings of 5th EAAP International Symposium on Energy and Protein Metabolism and Nutrition, 12-15 September 2016, Krakow, Poland, pp. 285-287.

Lamminen M, Halmemies-Beauchet-Filleau A, Kokkonen T, Simpura I, Jaakkola S and Vanhatalo A 2017. Comparison of microalgae and rapeseed meal as supplementary protein in the grass silage based nutrition of dairy cows. Animal Feed Science and Technology 234, 295-311.

Lamminen $M$, Kokkonen $T$, Halmemies-Beauchet-Filleau A, Termonen $T$, Vanhatalo A and Jaakkola S 2015. Partial replacement of grass silage with faba bean whole-crop silage in the diet of dairy cows. In Proceedings of the 18th Symposium of the European Grassland Federation, Grassland and forages in high output dairy farming systems, 15-17 June 2015, Wageningen, The Netherlands, pp. 446-448.

Lawrence RD, Anderson JL and Clapper JA 2016. Evaluation of camelina meal as a feedstuff for growing dairy heifers. Journal of Dairy Science 99, 6215-6228.

Lawrence RL and Anderson JL 2015. Ruminal degradation and intestinal digestibility of camelina and carinata meal compared with other protein sources. Journal of Dairy Science 98 (suppl. 2), 459. 
Halmemies-Beauchet-Filleau, Rinne, Lamminen, Mapato, Ampapon, Wanapat and Vanhatalo

Lindberg JE, Lindberg G, Teräs J, Poulsen G, Solberg SØ, Tybirk K, Przedrzymirska J, Sapota GP, Olsen ML, Karlson H, Jóhannsson R, Smárason BÖ, Gylling M Knudsen MT, Dorca-Preda T, Hermansen JE, Kruklite Z and Berzina I 2016. Nordic alternative protein potentials: mapping of regional bioeconomy opportunities. Nordic Council of Ministers. Retrieved on 26 July 2017 from http:// www.nordic-ilibrary.org/environment/nordic-alternative-protein-potentials_ tn2016-527

Lodge-Ivey SL, Tracey LN and Salazar A 2014. Ruminant nutrition symposium: the utility of lipid extracted algae as a protein source in forage or starch-based ruminant diets. Journal of Animal Science 92, 1331-1342.

Luke (Natural Resources Institute Finland) 2018. Feed tables and nutrient requirements. Retrieved on 27 November 2018 from www.luke.fi/feedtables.

Maia MRG, Fonseca AJM, Oliveira HM, Mendonça C and Cabrita ARJ 2016. The potential role of seaweeds in the natural manipulation of rumen fermentation and methane production. Scientific Reports 6, 32321.

Makkar HP, Cooper G, Weber JA, Lywood W and Pinkney J 2012. Biofuel coproducts as livestock feed. Opportunities and challenges. Food and Agriculture Organization, Rome, Italy.

Makkar HP, Tran G, Heuzé V, Giger-Reverdin S, Lessire M, Lebas F and Ankers P 2016. Seaweeds for livestock diets: a review. Animal Feed Science and Technology 212, 1-17.

McAllan AB 1982. The fate of nucleic acids in ruminants. Proceedings of the Nutrition Society 41, 309-316.

McEniry J and O'Kiely P 2014. Chapter 11: developments in grass-/forage-based biorefineries. In Advances in biorefineries - biomas and waste supply chain exploitation, Woodhead Publishing Series in Energy: Number 53 (ed. K Waldron), Library of Congress Control Number: 2014931606, pp. 335-363, Woodhead Publishing, Cambridge, UK.

Milano J, Ong HC, Masjuki HH, Chong WT, Lam MK, Loh PK and Vellayan V 2016. Microalgae biofuels as an alternative to fossil fuel for power generation. Renewable and Sustainable Energy Reviews 58, 180-197.

Millett MA, Baker AJ, Feist WC, Mellenberger RW and Satter LD 1970. Modifying wood to increase its in vitro digestibility. Journal of Animal Science 31, 781-788.

Millett MA, Baker AJ, Feist WC, Mellenberger RW and Satter LD 1973. Pulp and papermaking residues as feedstuffs for ruminants. Journal of Animal Science 37 599-607.

Meale SJ, Chaves AV, He ML and McAllister TA. 2014. Dose-response of supplementing marine algae (Schizochytrium spp.) on production performance, fatty acid profiles, and wool parameters of growing lambs. Journal of Animal Science 92, 2202-2213.

Moate PJ, Williams RO, Hannah MC, Eckard RJ, Auldist MJ, Ribaux BE, Jacobs JL and Wales WJ 2013. Effects of feeding algal meal high in docosahexaenoic acid on feed intake, milk production, and methane emissions in dairy cows. Journal of Dairy Science 96, 3177-3188.

Mottet A, de Haan C, Falcuccia A, Tempioa G, Opioa C and Gerbera P 2017. Livestock: on our plates or eating at our table? A new analysis of the feed/ food debate. Global Food Security 14, 1-8.

Nasseri AT, Rasoul-Amini S, Morowvat MH and Ghasemi Y 2011. Single cell protein: production and process. American Journal of Food Technology 6, 103116.

Niemi P, Pihlajaniemi V, Rinne M and Siika-aho M 2017. Production of sugars from grass silage after steam explosion or soaking in aqueous ammonia. Industrial Crops and Products 98, 93-99.

Orosz S and Davies DR 2015. Short and long term storage of wet by-products fed by ruminants. In Proceedings of XVII International Silage Conference, 1-3 July 2015, Piracicaba, Brazil. pp. 200-242.

Panjaitan T, Quigley SP, McLennan SR and Poppi DP 2010. Effect of the concentration of Spirulina (Spirulina platensis) algae in the drinking water on wate intake by cattle and the proportion of algae bypassing the rumen. Animal Production Science 50, 405-409.

Panjaitan T, Quigley SP, McLennan SR, Swain AJ and Poppi DP 2015. Spirulina (Spirulina platensis) algae supplementation increases microbial protein production and feed intake and decreases retention time of digesta in the rumen of cattle. Animal Production Science 55, 535-543.

Pisulewski PM, Rulquin H, Peyraud JL and Verite R 1996. Lactational and systemic responses of dairy cows to postruminal infusions of increasing amounts of methionine. Journal of Dairy Science 79, 1781-1791.

Puhakka L, Jaakkola S, Simpura I, Kokkonen T and Vanhatalo A 2016. Effects of replacing rapeseed meal with fava bean at 2 concentrate crude protein levels on feed intake, nutrient digestion, and milk production in cows fed grass silagebased diets. Journal of Dairy Science 99, 7993-8006.

Ravindra P 2000. Value-added food: single cell protein. Biotechnology Advances $18,459-479$.

Rinne M, Dragomir C, Kuoppala K, Smith J and Yáñez-Ruiz D 2014. Novel feeds for organic dairy chains. Organic Agriculture 4, 275-284.

Rinne M, Kautto 0, Kuoppala K, Ahvenjärvi S, Willför S, Kitunen V, Ilvesniemi H and Sormunen-Cristian R 2016. Digestion of wood-based hemicellulose extracts as screened by in vitro gas production method and verified in vivo using sheep. Agricultural and Food Science 25, 13-21. Retrieved on 15 December 2017 from http://ojs.tsv.fi/index.php/AFS/article/view/46502.

Rinne M, Keto L, Siljander-Rasi H, Stefanski T and Winquist E 2018. Grass silage for biorefinery - palatability of silage juice for pigs and cows. Submitted to XVIII International Silage Conference, 24-26 July 2018, Bonn, Germany.

Rinne M, Winquist E, Pihlajaniemi V, Niemi P, Seppälä A and Siika-aho M 2017. Fibrolytic enzyme treatment prior to ensiling increases press-juice yield from grass silage. In Proceedings of the 8th Nordic Feed Science Conference, 13-14 June 2017, Uppsala, Sweden.Department of Animal Nutrition and Management Swedish University of Agricultural Sciences. Report 296. pp. 71-76. Retrieved on 15 December 2017 from http://www.slu.se/globalassets/ew/org/inst/huv/nfsc/ nfsc-2017-proceedings.pdf.

Röös E, Bajželj B, Smith P, Patel M, Little D and Garnett T 2017. Protein futures for Western Europe: potential land use and climate impacts in 2050. Regional Environmental Change 17, 367-377.

Saarinen P, Jensen W and Alhojärvi J 1959. On the digestibility of high yield chemical pulp and its evaluation. Acta Agralia Fennica 94, 41-64.

Savonen 0, Franco M, Stefanski T, Mäntysaari P, Kuoppala K and Rinne M. 2018. Grass silage for biorefinery - dairy cow responses to diets based on solid fraction of grass silage. Nordic Feed Science Conference, 12-13 June 2018, Uppsala, Sweden.

Schader C, Muller A, El-Hage Scialabba N, Hecht J, Isensee A, Erb K-H, Smith P, Makkar HPS, Klocke P, Leiber F, Schwegler P, Stolze M and Niggli U 2015. Impacts of feeding less food-competing feedstuffs to livestock on global food system sustainability. Journal of Royal Society Interface 12, 20150891.

Sjöström E 1993. Wood chemistry: fundamentals and applications (293 p. Academic Press, San Diego, CA, USA.

Smith J, Kuoppala K, Yáñez-Ruiz D, Leach K and Rinne M 2014. Nutritional and fermentation quality of ensiled willow from an integrated feed and bioenergy agroforestry system in UK. In Proceedings of Maataloustieteen Päivät 2014, 8-9 January 2014, Helsinki, Finland. 9 p. Retrieved on 15 December 2017 from http://www.smts.fi/MTP_julkaisu_2014/Posterit/064Smith_ym_Nutritional_ and_fermentation_quality_of_ensiled_willow.pdf.

Smith J, Leach K, Rinne M, Kuoppala K and Padel S 2012. Integrating willowbased bioenergy and organic dairy production - the role of tree fodder for feed supplementation. In Proceedings of the 2nd IFOAM Animal Husbandry Conference, 12-14 September 2012, Hamburg, Germany. vTi Agriculture and Forestry Research, Special Issue 362. pp. 417-420. Retrieved on 15 December 2017 from http://orgprints.org/21758/1/Smith_2OAHC\%20proceedings_2012. pdf.

Szumacher-Strabel M, Cieślak A, Zmora P, Pers-Kamczyc E, Bielińska S, Stanisz $M$ and Wójtowski J 2011. Camelina sativa cake improved unsaturated fatty acids in ewe's milk. Journal of the Science of Food and Agriculture 91, 2031-2037.

Tayyab U, Novoa-Garrido M, Roleda MY, Lind V and Weisbjerg MR 2016. Ruminal and intestinal protein degradability of various seaweed species measured in situ in dairy cows. Animal Feed Science and Technology 213, 44-54.

Tikam K, Phatsara C, Mikled C, Vearasilp T, Phunphiphat W, Chobtang J, Cherdthong $A$ and Südekum KH 2013. Pangola grass as forage for ruminant animals: a review. SpringerPlus 2, 604-609.

USDA 2016. Oil crops yearbook 2016. Retrieved on 15 November 2017 from http://usda.mannlib.cornell.edu/MannUsda/homepage.do.

Van der Spiegel M, Noordam MY and Fels-Klerx HJ 2013. Safety of novel protein sources (insects, microalgae, seaweed, duckweed, and rapeseed) and legislative aspects for their application in food and feed production. Comprehensive Reviews in Food Science and Food Safety 12, 662-678.

Van Emon ML, Loy DD and Hansen SL 2015. Determining the preference, in vitro digestibility, in situ disappearance, and grower period performance of steers fed a novel algae meal derived from heterotrophic microalgae. Journal of Animal Science 93, 3121-3129. 
Vanhatalo A, Huhtanen P, Toivonen V and Varvikko T 1999. Response of dairy cows fed grass silage diets to abomasal infusions of histidine alone or in combinations with methionine and lysine. Journal of Dairy Science 82, 2674-2685.

Van Krimpen MM, Bikker P, Van der Meer IM, Van der Peet-Schwering CMC and Vereijken JM 2013. Cultivation, processing and nutritional aspects for pigs and poultry of European protein sources as alternatives for imported soybean products (No. 662). Wageningen UR Livestock Research, Lelystad, The Netherlands Wadhwa M and Bakshi MPS 2013. Utilization of fruit and vegetable wastes as livestock feed and as substrates for generation of other value-added products. FAO Publication 2013/04. H.P. Makkar Technical Editor. Retrieved on 15 December 2017 from http://www.fao.org/docrep/018/i3273e/i3273e.pdf.

Wadhwa M, Bakshi MP and Makkar HP 2015. Waste to worth: fruit wastes and by-products as animal feed. CAB Reviews 10, 1-26.

Wanapat M 2009. Potential uses of local feed resources for ruminants. Tropical Animal Health and Production 41, 1035-1049.

Wanapat M, Foiklang S, Ampapon T, Mapato C and Cherdthong T 2017. Feeding strategy on farms to improve livestock productivity and reduce methane production. In Proceedings of the 2nd International Conference on Animal Nutrition and Environment, 1-4 November 2017, Khon Kaen, Thailand, pp. 14-29.

Wanapat M and Kang S 2015. Cassava chip (Manihot esculenta Crantz) as an energy source for ruminant feeding. Animal Nutrition 1, 266-270.

Wanapat M, Kang S and Polyorach S 2013. Development of feeding systems and strategies of supplementation to enhance rumen fermentation and ruminant production in the tropics. Journal Animal Science and Biotechnology 4, 32.
Wasilewko J and Buraczewska L 1999. Chemical composition including content of amino acids, minerals and alkaloids in seeds of three lupin species cultivated in Poland. Journal of Animal and Feed Sciences 81, 1-12.

Watson CA, Reckling M, Preissel S, Bachinger J, Bergkvist G, Kuhlman T, Lindström K, Nemecek T, Topp CFE, Vanhatalo A, Zander P, Murphy-Bokern D and Stoddard $F$ 2017. Chapter four-grain legume production and use in European agricultural systems. Advances in Agronomy 144, 235-303.

White $\mathrm{CL}$, Staines VE and Staines MvH 2007. A review of the nutritional value of lupins for dairy cows. Australian Journal of Agricultural Research 58, 185-202.

Wilkinson JM and Rinne M 2018. Review. Highlights of progress in silage conservation and future perspectives. Grass and Forage Science 73, 40-52.

Xiu S and Shahbai A 2015. Development of green bioefinery for biomass utilization: a review. Trends in Renewable Energy 1, 4-15.

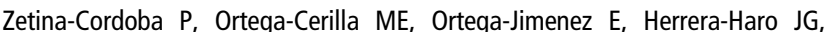
Sanchez-Torres-Esqueda MT, Reta-Mendiola JL, Vilaboa-Arroniz J and MunguiaAmeca G 2013. Effect of cutting interval of Taiwan grass (Pennisetum purpureum) and partial substitution with duckweed (Lemna sp. and Spirodela sp.) on intake, digestibility and ruminal fermentation of Pelibuey lambs. Livestock Science 157, 471-477.

Zinn RA 1990. Feeding value of wood sugar concentrate for feedlot cattle. Journal of Animal Science 68, 2598-2602.

Zinn RA 1993. Comparative feeding value of wood sugar concentrate and cane molasses for feedlot cattle. Journal of Animal Science 71, 2297-2302. 